\title{
A LOOK AT LESOTHO GOVERNMENT AND NGOS' ECONOMIC EMPOWERMENT PROGRAMS WITH RESPECT TO RURAL POVERTY REDUCTION
}

INNOCENT HAPAZARI - JOSPHINE HAPAZARI ${ }^{1}$

\begin{abstract}
This study examined ongoing economic empowerment programs that are being implemented by both government and NGOs in rural areas of Lesotho. The key objectives were to gain some insight into major government and NGO poverty reduction programs that target or at least include the rural poor, and to establish the challenges encountered by the benefactors in executing their poverty reduction efforts. A qualitative approach involving interviews was utilized to collect data from a sample of six government ministries and six NGOs. The study revealed that various economic empowerment programs were being implemented throughout the country. The main challenges faced by the government and NGOs in their quest to assist the rural poor were constrained resources, inadequate cooperation and/ or interference from political leadership, and the insufficient enthusiasm of target groups.
\end{abstract}

KEYWORDS: economic empowerment programs, poverty reduction, Lesotho Government, $N G O s$

\section{INTRODUCTION}

Lesotho is an African 'third-world' country, which, by both international and regional standards, is ranked among those at the lower end of the economic ladder among its fellow African countries. It is due to this fact that the role of government and NGOs in relation to poverty reduction is central to the country.

\footnotetext{
1 Hapazari, Innocent (corresponding author) is a senior lecturer at the Department of Chemistry and Chemical Technology, National University of Lesotho, Roma 180, Lesotho, e-mail: i.hapazari@ nul.1s, or ihapazari@yahoo.com. Hapazari, Josphine is a PhD student at the School of Social Sciences, Howard College, University of KwaZulu Natal, Durban, South Africa, e-mail: jbhiri. hapazari@gmail.com .
} 


\section{Socioeconomic features of Lesotho}

Lesotho is a mountainous landlocked country which is unique by being completely surrounded by the Republic of South Africa (RSA). It is geographically located in the south-eastern part of RSA and shares a border with three of RSA's ten provinces - namely, Free State, Eastern Cape, and KwaZulu-Natal. The country has an estimated geographical area of 30,355 sq. $\mathrm{km}$ and is divided into ten geopolitical districts (LMS 2013). Its population is estimated at around 2.14 million people (UN/DESA-Population Division 2015). About $76 \%$ of the population is rural-based (Taele 2012), and the main economic activities of the former are crop farming and animal husbandry. Lesotho's literacy level is over $90 \%$, while average life expectancy is about 49 years (UNDP/Lesotho 2014). The country's GDP is approximately USD 2,278 billion and GNI per capita for 2015 was estimated at USD 1,280. The unemployment and poverty rates for 2013 were estimated at 57\% and 30\%, respectively (World Data Bank 2012). Hapazari (2017) attributes Lesotho's high levels of poverty and unemployment to the country's small economy and insufficient arable land. The high level of poverty in Lesotho may also be attributed to poor soils, degraded rangelands and a volatile climate which combine to hold back progress on eradicating extreme poverty and hunger (Government of Lesotho 2014). The high levels of unemployment are also accompanied by and/or give rise to under-employment, in relation to which, for instance, the majority of the country's adult females are employed in textile industries and domestic work where they earn very low salaries (Hapazari 2016). The scourge of unemployment is more pronounced in rural areas compared to urban areas. It is the authors' view that the political instability that started around 2012 and continues to this day - which climaxed in the collapse of two governments and the holding of three national elections within a period of five years (2013-2017) - has its roots in the unhealthy economic situation of the country. From this point of view, the authors assert that the holistic economic empowerment of the country's majority poor deserves special attention and could be the ultimate panacea for the country's problems that are manifesting themselves in various ways, such as in political instability.

This study set out to answer the following research questions:

1. What are the economic empowerment programs that are being implemented by the Lesotho government in rural areas?

2. What are the economic empowerment programs that are being implemented by NGOs in the rural areas of Lesotho?

3. To what extent are the programs succeeding in achieving the intended goal of poverty reduction? 
4. What challenges are encountered by the benefactors in executing their poverty reduction efforts?

\section{LITERATURE REVIEW}

The responsibility for the economic empowerment and advancement of the economically disadvantaged groups of any country squarely rests with their national governments. However, non-governmental organizations (NGOs), though not necessarily duty-bound in the same manner as national governments, have traditionally played critical roles in the economic empowerment and advancement of the poor the world over. In essence, it can be argued that NGOs have created some legitimate expectations among the poor of the world, especially in developing countries.

Keman (2017) refers to government as an institutionalized process through which public order is maintained and collective action is organized so as to enhance the welfare of society. The beauty of this definition is the fact that it includes the government's role of enhancing the welfare of society. In short, governments are purposefully created to serve their societies by facilitating prosperity and social cohesion. Arguably, this definition of the role of government would resonate with the majority of the citizenry of countries the world over. Handley (2009) argues that the role of government in social protection and development is now widely acknowledged by both donors and governments themselves as key to poverty alleviation and economic growth. Twala (2012) asserts that poverty reduction and alleviation aims at reducing the negative impacts of poverty on the lives of poor people and includes the state's social grant programs which can reduce the impact of poverty for many people.

The term non-governmental organization (NGO) has been multifariously defined. However, the authors find the definitions by Lewis and Kanji (2009) and Vakil (as cited in Lewis and Kanji 2009, p. 11) very captivating. Lewis and Kanji define NGOs as agencies that are primarily engaged in work relating to some areas of development or humanitarian work at a local, national or international level. Vakil defines NGOs as "self-governing, private, not-for-profit organizations that are geared to improving the quality of life of disadvantaged people." There is no doubt that these definitions strongly resonate with the majority understanding of what NGOs stand for, and they both capture the critical issue of human development, which cannot in any case be separated from economic empowerment. Suffice to say, while NGOs play multifaceted roles within the societies they operate, their key purpose and underpinning principle is the betterment of the lives of people within their target communities. 
Empowerment as a tool for advancing economically and politically disadvantaged groups is an ongoing process and is not in any way confined to any particular continent, region or country. Gender-related empowerment also remains an important issue that is still getting global attention. For example, in 2008 the European Commission adopted regulation which extends the granting of state aid to new enterprises created by women (OECD 2014) as a means of empowering women. The OECD (2014) also states that Norway has the highest proportion of women on the boards of listed companies (at close to $40 \%$ ) due to its quota legislation of 2006, which is also meant to empower women. The Australian Government (2017) highlights that Australia played a crucial role in establishing Women 20 (W20), a G20 sub-group. The focus of W20 is primarily promoting gender-inclusive growth and advancing G20 commitments related to women's empowerment. In line with these commitments, Australia is working to reduce the gap between women and men in the workforce by 2025 (Australian Government 2017).

Within the Southern African region, various empowerment programs have been implemented and are ongoing in different countries. Beierl et al. (2017) highlights that in 2006 the Malawian government launched a Social Cash Transfer Programme targeting the ultra-poor (10 percent of the poorest households in each district) as well as labor-constrained households. The program's primary aim was to alleviate poverty and food insecurity in rural areas. Diraditsile (2017) noted that, in its efforts to empower youth, Botswana has developed various policies and programs, including the Youth Policy of 1996, and the Revised Youth Policy of 2010, the Out of School Youth Program, the Young Farmers' Fund, Youth Development Fund, Botswana National Internship Programme, and the Graduate Volunteer Scheme. Kumar et al. (2018) states that the RAIN project was implemented in Zambia's Mumbwa district between 2011 and 2015. The project involved an agricultural intervention focused on homestead food production aimed at increasing the year-round availability of and access to nutrient-rich foods at the household level.

Kali (2018) observed that while Lesotho has taken some steps regarding the empowerment of women, the gender-based measures implemented by the government have mostly been flawed and need some rectification if they are to genuinely empower women, otherwise they will remain only good intentions. Sekatle (2010) notes that in 2004 the Lesotho parliament passed legislation reserving at least thirty percent (30\%) of its seats for women. Interestingly, soon after this affirmative action by parliament ordinary voters seemed to have taken their cue and responded favorably to women candidates to the extent that women now occupy $58 \%$ of the electable positions in the country's local governments. With regard to education, Lesotho's literacy rate has escalated to 
$95 \%$ for women, as opposed to $83 \%$ for men, creating an overall literacy rate of about $90 \%$ (UNDP 2015). While the literacy gap between females and males cannot be attributed to any targeted program, the country's overall literacy rate, which ranks Lesotho among the top countries in Africa, can very much be attributed to the country's Free Primary Education Policy of 2000 and the subsequent Compulsory Free Primary Education legislation contained in the country's Education Act of 2010.

Rantšo (2015) highlights that the government of Lesotho has partnered with parastatal and private organizations, including the Lesotho Revenue Authority (LRA), Standard Lesotho Bank, and the Basotho Enterprise Development Corporation (BEDCO) to fight the scourge of youth unemployment through a program called 'Bacha Entrepreneurship.' The program is financed to the tune of M 500,000 (USD 37,313) per year. Assistance from this program is accessed on a competitive basis. For instance, Rantšo indicated that a call for applications for start-up capital from the program from youth business groups had been made in December 2014 for the year 2015. The present authors cite this specific program because it fits very well into the scope of the present study, since it entails empowering the unemployed within the study period under consideration - that is, between 2010 and 2015.

Due to persisting gender inequalities worldwide, most of the literature on economic empowerment only covers women. The research associated with this study sampled both men and women, thereby helping fill this literature gap. This study is also very important as it enriches existing literature by specifically highlighting the Lesotho context.

It is with the aforementioned understanding of the roles of governments and NGOs that the authors found it worthwhile to explore and identify the kind of economic empowerment programs currently offered by these critical players, particularly to poor communities; moreover, also in relation to obtaining insight into the impact of such problems with regard to the need for the reduction of poverty and trying to understand the nature of the challenges the former face as they implement such programs. The driving force is the authors' observation, through various informal and formal interactions with members of society, that there is a lack of information, especially among the poor, regarding governmentand NGO poverty-reduction programs of which they may be among the target beneficiaries. 


\section{METHODOLOGY}

The study adopted a qualitative approach, employing a study sample consisting of six government officials and six NGO officials, each from a different government ministry or NGO, respectively. Polkinghorne (2005) illuminates the fact that qualitative research involves investigations aimed at describing and clarifying human experience as it occurs in people's lives. The ministries and NGOs were purposefully identified. Hence, only those ministries whose main goal is the economic empowerment of disadvantaged groups, and those NGOs identified to be present in relatively high numbers in the country's ten districts, were targeted. Two interview guides were utilized to collect qualitative data from the officials. On the basis of the interview guides, the officials provided information about the economic empowerment programs or poverty reduction interventions employed by their respective ministries or NGOs.

In addition, policy documents, where available, were scrutinized to ascertain official positions on the economic empowerment programs of ministries. Qualitative data analysis was employed. First of all, data were transcribed from the recorded audio recordings. Thereafter, the data were coded according to emerging themes, and in line with the research questions.

\section{RESULTS AND DISCUSSION}

This section reveals and discusses the various ongoing economic empowerment programs of the respondent government ministries and NGOs. Notably, various programs and strategies are employed by different government ministries and NGOs in their pursuit of the economic empowerment of poor and unemployed people in Lesotho.

\section{On-going Government Economic Empowerment Programs}

The six ministries targeted for this study due to their central focus on poverty reduction efforts were: 1) the Ministry of Gender, Youth and Sports and Recreation (MGYSR), 2) the Ministry of Forestry and Land Reclamation (MFLR), 3) the Ministry of Social Development (MSD), 4) the Ministry of Agriculture and Food Security (MAFS), 5) the Ministry of Small Business Development, Co-operatives and Marketing (MSBDCM), and 6) the Ministry of Labour and Employment (MLE). 
The MGYSR economically empowers the poor and unemployed through skills development in technical areas, including jewellery production, shoemaking, crocheting, sewing, and agriculture. The ministry conducts such training at vocational centers across the country's ten districts. The training program includes various aspects of entrepreneurship, financial management, and marketing. Accordingly, those who have undergone such training not only gain technical skills but are also in a better position to start their own income generating projects and to effectively manage them. The ministry also provides assistance to those who already produce or manufacture products by identifying possible markets and even negotiating with the markets on their behalf. Although the researchers could not obtain any quantitative data with regard to the impact of the ministry's efforts, officials asserted that their efforts are yielding positive results. The dominance of the informal industry in a country characterized by a strong presence of craftsmen, many of whom might have benefited from the ministry's programs, to some extent seems to corroborate official assertions.

The MAFS economically empowers poor people through its famous tree-planting-for-poverty-reduction program, which was said to have been running since 2011. This is a countrywide program operated in two different but complimentary modes. One approach involves the ministry supplying target beneficiaries - mainly poor rural people - with young forest- (pine, eucalyptus, and some indigenous) and/or fruit- (peach, apple, and plum) trees for free. Beneficiaries plant these, thereby creating their own woodlots and orchards, from which they benefit both through personal consumption and through the sale of products. Such products include firewood and construction materials in the case of forestry trees and fruit in the case of fruit trees. Furthermore, the ministry also trains people in how to grow and maintain their own forestry plots (woodlots) and orchards.

The second approach involves the ministry training and encouraging people to establish nurseries for fruit and forestry trees which may then be sold to the ministry, which requires them for distribution to the beneficiaries of the first initiative. Hence, there is a symbiotic relationship between the ministry's two approaches. The officials asserted that, although the ministry has its own nurseries in all districts of the country, their own supply capacity is much less than the targeted number of nursery trees they seek to distribute annually, hence the two programs cannot exist independently. It was also highlighted that the ministry has never exhausted its budget for buying nursery trees - particularly fruit trees - since the program started, and moreover, that annual distribution targets are not met due to a supply-side deficiency. Effectively, the ministry would like to have as many people as possible engaged in the nursery programs 
so that an adequate supply of trees is available. However, this needs suitable land and a reliable source of water, especially during the summer season.

It was also highlighted that the objectives of the program are multipronged - covering provision of access to nutritious fruit that improves the nutritional status of communities, income generation, and environmental conservation through combating soil erosion. Similarly, Leakey et al. (2003) stress that increasing the number of fruit trees could play a significant role in combating poverty in the forest zone of West and Central Africa.

In addition, the ministry also economically empowers poor and unemployed people by imparting a variety of technical skills, including bee keeping and harvesting and processing of honey, and marketing. Such skills are generally taught to interested groups who normally organize themselves into cooperatives and approach the ministry. The ministry also organizes occasional training programs at its agricultural training colleges that target any interested members of the public.

The ministry, however, lamented the lack of program-supporting budgets as a key challenge. It was highlighted, for instance, that the budget does not provide any funds to support those who want to start income-generating projects such as tree planting and who lack basic infrastructure such as boreholes, water pumps and pipes which would require a capital injection. The lack of capital of the target groups, coupled with the ministry's small budget which excludes financialsupport schemes, was highlighted as a major constraint to the ministry's economic empowerment efforts as it has led to a lower uptake of the program than anticipated. Operationally, a lack of cooperation and interference from political leadership at various levels was also noted as somewhat of a source of frustration and impediment to professionals when executing their duties. A lack of enthusiasm and dependence-syndrome was also cited as another challenge. It was argued that there are instances when some poor families have the basic resources to participate in some simple and straightforward programs that would earn them much-needed income, but they fail to engage. Examples cited included poor families who have land with suitable types of soils as well as proximity to a reliable water source who do not participate in the nursery planting program despite being well aware of it.

With regard to the impact of their programs in reducing poverty, the ministry contends that its efforts are going a long way towards meeting objectives, notwithstanding the highlighted constraints. The officials argued that the area covered by forestry woodlots and orchards in the communities across the country has progressively increased over the years. The progressive increase in the number of fruit vendors in city streets and on countryside roads can also be seen as vindication of the impact of the programs. The researchers also 
interviewed ten (10) nursery farmers in Maseru district, targeting those who had been farming for at least the past five (5) years. The former reported annual earnings ranging from about USD $1000-10,000$, with those at the higher end indicating that they get assistance from family members or hired labor, while most of those at the lower end work alone. The researchers found this to be a positive indicator of the effectiveness of the ministry's programs, as they have successfully created employment for such farmers.

The MSD runs a total of five social welfare schemes or programs that target the poor and vulnerable members of the community; namely, a Public Assistance, Cash Grant, Secondary Education Bursary, Social Welfare Institution Grant, and a Vocational Rehabilitation program. The public assistance scheme is delivered either in cash or in kind and targets the poorest of the poor within the communities. Beneficiaries are identified by professionals, especially social workers. Currently, assistance in cash amounts to USD 21 (i.e., about M 250) per beneficiary per month. On the other hand, assistance in kind is in the form of food packages and clothes.

The officials indicated that the program has always been in place - which the researchers understood to simply mean that the program has been in place for a long time and the respondents did not know or could not recall when it commenced.

The cash grant program instituted in 2009 targets poor households that are taking care of orphans. Under this program, needy families who take care of orphans receive varying amounts of cash in the form of grants which currently are paid quarterly and are pegged at USD 30, USD 50 and USD 62.50 per quarter, depending on the number of orphans being taken care of. The lowest payout (USD 30) is offered to households who care for up to two orphans, while the highest (USD 62.50) applies to more than four orphans.

The selection process for the beneficiaries of the cash grant program is fundamentally different from the public assistance program in the sense that it is implemented by Village Assessment Committees (VAC) that are set up at the village level whose members do not necessarily need to have any professional training. The officials could not articulate the wisdom behind the difference in the selection processes, although the researchers intuitively found the use of VAC to be quite suspect. Using untrained village members to make up the VAC and execute a process which ideally requires a high level of impartiality unsettled the researchers, who found it very difficult to imagine that such untrained and neighboring community members are able to fairly adjudicate matters that should benefit just a few of the most deserving cases within their neighborhoods - given that there are always close relatives and friends in the vicinity who may be potential beneficiaries but who are not the most deserving cases. 
The secondary education bursary scheme is a cash grant that specifically goes to help pay the school fees of vulnerable learners at the secondary school level. The scheme is accessed upon assessment and verification of the need for such assistance. A basic criterion for selection of potential beneficiaries is that the learner must be attending any class between Form A and Form $\mathrm{E}$ at a public or government school, and be either a double orphan or have a single parent who is poor and unemployed.

Through its social welfare institution grant, the MSD provides subventions to orphanages and old peoples' homes as a way of economically empowering the vulnerable groups cared for by those institutions. Notably, Lesotho government currently does not own any orphanages or homes for the elderly; hence, this extension of support to privately owned institutions is critical as it serves as a demonstration of the government's appreciation of the vital societal role being played by those private players in partial fulfillment of its own social obligations. Therefore, collaboration between the government and NGOs in this regard is plausible. However, it would be ideal if government led from the front in terms of taking care of older citizens and orphans.

Last, the MSD also runs the Ithuseng Vocational Rehabilitation Centre where various skills are imparted to disabled people to promote their independence, which is again a very plausible endeavour of the government. The disabled are taught various skills ranging from technical to business skills depending on the nature of the individual disabilities. The training is generally meant to make the individuals economically active in one way or another. In terms of impact, the official narrative is that this a very effective and successful scheme, and that many trainees of the training centre are now formally employed (and the majority self-employed) in the informal sector. The authors are generally in agreement with such assertions because it is indeed true that people with disabilities are quite visible in the formal and informal sectors of Lesotho where they lead normal working lives. In fact, the authors argue that Lesotho is one of the very few countries in Africa where very few disabled people beg for cash or food, etc. on the streets.

With regard to challenges, the officials intimated that their budgets allocations always fall short of the demands of the ministry's mammoth tasks. Consequently, every year the ministry fails to attend to a number of needy situations that have been brought to its attention due to a lack of resources, including manpower. Political interference was also cited as a factor that frustrates professionals in the course of their work. Various political actors very often put pressure on the ministry's staff, either demanding that relatively larger shares of resources are channeled toward particular regions in which they have interests, or that individuals they favor are made beneficiaries ahead of more needy cases. 
The Ministry of Agriculture and Food Security (MAFS) indicated that whilst it does not have any economic empowerment programs specifically targeted at poor and unemployed people, it does play a critical role in assisting the broader community through selling farming inputs and products at subsidized prices. Ironically, more than $70 \%$ of Basotho are classified as poor, rural-based and agro-dependent [LMS 2013]. Accordingly, one would think this would be the ministry most strategically placed through which the government could channel a plethora of agro-focused rural economic empowerment programs in its effort to fight poverty. In any case, the economic improvement of those living in poverty fundamentally starts with putting food on their tables (Hapazari, 2016). Hence, the confessed lack of any targeted programs such as agricultural extension services to at least boost the rural poor's subsistence farming skills and possibly guarantee the provision of much-needed food on their tables was rather chilling.

The Ministry of Small Business Development, Co-operatives and Marketing (MSBDCM) primarily contributes to economic empowerment through imparting entrepreneurial skills to community members in general. As a result, the ministry does not target any specific group. Its training programs are open to anyone who comes forward and registers as and when such programs are offered, and enrolment is on first-come first-served basis. The ministry basically uses two approaches to deliver its training programs. One is that the ministry mobilizes and encourages people to form groups of sizeable numbers or even cooperatives which can then request training from the ministry, which in turn organizes suitable training venues in the localities of such organized groups. This approach ensures that participants do not have travel to cities or far away from their homes where they would have to incur accommodation and transport costs. Second, the ministry initiates its own public gatherings in the form of training workshops where everyone who can be accommodated at the workshop venue can participate and receive information. It was highlighted that the aim is to train and equip as many people as possible, including the unemployed, with entrepreneurial knowledge and skills, so as to enable them to innovatively identify and/or create viable livelihood opportunities and mobilize the requisite resources to profitably pursue various opportunities. The ministry asserted that the impact of its efforts are hardly quantifiable but it believes that its endeavors are contributing significantly towards poverty reduction poverty and national development. The officials also argue, although they had no quantitative figures, that it was obvious that a significant number of people engaging in some income-generating projects in both formal and informal sectors have benefited from their training programs at one point or another. 
The Ministry of Labor and Employment basically plays three key roles in relation to assisting unemployed people. First, it acts as an employment agency - linking job seekers and potential employers. The ministry has an employment helpdesk that maintains a database of job seekers and their curriculum vitae together with other relevant details, and continuously crosschecks advertisements vis-à-vis its database to see if there are any matches. Potential employers are also welcome to approach the ministry, and their requirements are also registered for use in similar employer-employee matching processes. The ministry argues that this is a vital program in the sense that it ensures that prospective employers and employees easily find each other. Furthermore, it ensures that workers are not underemployed by placing individuals in suitable jobs. The ministry also provides pertinent labor-relations-related information to both employees and employers - a role which one official argued to be particularly critical to employees in terms of equipping them with information about their rights as workers. However, while official claims appear very sound on paper, the reality is that suitable jobs are very scarce in the country. Lesotho is characterized by high levels of unemployment, due, among other factors, to its rather small economy with very little manufacturing activity. As such, it could be argued that, noble as it may seem, the program tends to create false hope, especially among new graduates (i.e. prospective employees) of training or learning institutions who may become frustrated and dejected after a long and fruitless wait for a job. The ministry's approach of just assisting job seekers to meet potential employers contrasts with the approach in Botswana whereby the Ministry of Local Government and Rural Development, through the Ipelegeng Program, strives to fight poverty by creating employment opportunities for poor people (Nthomang 2018).

Second, the ministry encourages unemployed people to form self-financing groups and venture into income-generating projects. Self-financing means that group members have to pool their resources by contributing a pre-agreed amount of cash to enable them to engage in income-generating projects of their choice. The provision of funding is beyond the scope of the ministry's programs. However, the ministry provides such groups and unemployed individuals with business skills, such as knowledge about financial management and marketing, how to identify business gaps, how to run co-operatives, and dispute resolution skills.

The officials reported that their key challenge was the small budgetary allocation which makes it difficult to offer effective training to all those who would be willing. The small budgets restrict the number of training sessions that may be conducted per financial year, the place and venue for training, and the ministry's capacity to recruit sufficiently qualified and experienced personnel 
or to outsource consultancy services for training when necessary. It was also noted that the idea of pooling resources as a co-operative does not seem to be well received by the unemployed poor. The success of such a program requires a lot of cooperation from unemployed people who have to be fully committed to participate in the program. The officials believed that their efforts were having a positive impact on the livelihood of the poor, although such impacts could not be easily quantified.

\section{Ongoing NGO Economic Empowerment programs}

NGOs also employ a myriad of strategies in their efforts to economically empower Lesotho's unemployed people and the rural poor. The strategies employed by respective NGOs largely depend on factors such as the genesis, nature and agenda of the particular organization. Notwithstanding the existence of a much larger number of NGOs in the country, including those under the umbrella of big international bodies such as the UN, only six NGOs were focused upon here. These were the Ex-miners Association, Caritas Lesotho, United Textile Employees, Lesotho Homemakers Association, Send-a-Cow, and the Rural Self-Help Development Association.

The Ex-miners Association is an association of former South African mine workers whose focus is to assist ex-miners and families, particularly dependents of deceased ex-miners. Fundamentally, the organization brings the former miners together as a united force to advocate and fight for fair and equitable post-employment benefits for both relatives of the deceased, and surviving exminers. The association pays particular attention to the ex-miners who worked in South African gold mines under the famous Witwatersrand Native Labour Association (WNLA), once a recruiting agent for migrant labor which was popularly known across Southern Africa and beyond as WENELA, whose activities are reported to have started in the 1940s and which ended in the early 1980s.

The association gathers all relevant information and documents from the exminers or their next of kin to enable them to launch claims for the payment of overdue benefits which are still locked up in the Mine Workers' Provident Fund (domiciled in South Africa). Successful claims are paid to the organization in lump sums, and the organization, which ideally acts as a trustee, provides financial assistance to surviving ex-miners or dependents of deceased exminers for subsistence purposes. The organization also provides capital to bona fide beneficiaries for income-generating projects. The funds sustaining the organization are actually the pensions and other benefits accrued by individual 
ex-miners during their working lives which have not been paid out over the years. However, the researchers could not establish the proportion of successful claims that are retained by the organization to sustain its activities in relation to those that are paid out to the individual ex-miners or dependents on behalf of which the claims are launched.

Some of the challenges highlighted by the organization included the issue of slow information dissemination processes, meaning that there are still a huge number of ex-miners or dependents of ex-miners across the country, especially in rural areas, who are not aware of the organization's existence. Consequently, many ex-miners or bona fide dependents of ex-miners remain unaware of the existence of funds to which they could be entitled; hence they continue to live in poverty. The lengthy period before such claims can be made was also cited as a huge challenge, as in many cases some of the key documents required for launching the claims have been lost. The secretive culture of some African men was also said to be a problem, since many widows and dependents of deceased ex-miners are unaware of any potential benefits, even though the deceased knew of them.

Suffice to say, any discrepancies and challenges notwithstanding, the researchers got the impression that the organization is doing a sterling job of helping to uplift a very vulnerable group of Basotho people. This claim is in line with the view of Edwards (1999) that NGOs need to operate as autonomous institutions in order to assist the poor effectively. However, it is also the researchers' view that the organization needs to enhance its visibility by engaging in more extensive national awareness campaigns. It was also not very clear to the researchers how transparency is ensured, especially with regard to ensuring that the poor ex-miners, on whose behalf such claims are made, receive their fair share from the organization. Even the role of government, if any, was not clarified, which the researchers found rather startling. One would think - since significant quantities of money belonging to poor and vulnerable citizens are involved - that the government would play a larger role in ensuring transparency.

Caritas Lesotho, founded in 1970, and a member of Caritas Internationals and Caritas Africa, is another prominent NGO operating in Lesotho whose representatives were respondents in this research. The organization receives most of its support from global national Caritas members such as Catholic Relief Services USA. Its economic empowerment activities focus on imparting technical skills by offering and sponsoring the training of vulnerable groups, especially orphans. Inter alia, the technical skills that are offered are in the areas of woodwork and farming, and are largely aimed at fostering selfemployment. Apart from imparting technical skills, the organization also offers 
career guidance to vulnerable children, particularly in rural areas where a lack of such information is glaringly acute. While the efforts by Caritas Lesotho are commendable, some researchers have argued that NGOs and donor-funded programs normally come with technical staff, a phenomenon that denies recipients the chance to develop their own capacity to design and manage such programs, which is disadvantageous (Del Nnino et al. 2009).

United Textile Employees is another NGO with visibility in Lesotho, and is a brainchild of local people - mainly textile industry workers - who say that their aim is to give back to their community by imparting technical and lifesustaining skills to unemployed people; particularly those skills they have acquired through work experience or training. Hence, the technical skills offered by this NGO are largely skewed towards the textile sector; they include tie-and-dye, knitting, tailoring, and crocheting. In addition, the NGO also trains students in a variety of sporting activities and other life skills. This is probably an organization whose impact cannot be over-emphasized. It is a fact that the textile industry is the largest formal sector (in terms of headcount) in Lesotho. The researchers note that the informal manufacturing sector in most cities of Lesotho is predominantly textile-related. Thus, despite the absence of quantitative data one can reasonably suppose that a significant number of Basotho who are eking a living from textile-related activities have benefited from the activities of this particular organization.

The Lesotho Homemakers Association economically empowers the poor and unemployed through imparting various skills, including those related to cookery, gardening, tailoring, and crocheting. The organization largely operates in Maseru and a few other urban centers, restricting its accessibility to the rural poor. Suharko (2007) emphasized that, due to a lack of resources, some NGOs assist very few people. This is rather unfortunate for Lesotho given that majority of the vulnerable and poor Basotho are rural-based. One can only wish that in due course such organizations will acquire sufficient capacity to take their noble activities to deeply rural areas where most of the poor and unemployed reside. The concentration on urban areas by such organizations will serve to perpetuate the challenges that are associated with the urban-rural economic imbalance such as rural-to-urban migration and its concomitant socioeconomic impact.

Send-a-Cow is an international NGO established in 1988 that has been operating in Lesotho since about 2002. The organization fundamentally helps rural poor people in many African countries through agricultural development programs. Send-a-Cow Lesotho primarily focuses on sustainable farming projects in rural areas. It offers agricultural inputs to its beneficiaries in the form of seeds, fruit-tree seedlings, poultry chicks, rabbits and goats and training in good farming and environment conservation practices to combat harmful 
phenomenon such as soil erosion, and builds capacity to sustain the projects after initial assistance is awarded. It also helps by providing nets to protect vegetable gardens (against hail). It was revealed that, to date, the organization has assisted and continues to work with more than 3,000 Basotho households, many of which are severely affected by adverse health and macroeconomics scourges such as HIV/AIDS and climate-related disasters. One can rightly say that this NGO is having a significant impact on the lives of poor Basotho, since reaching 3,000 households, at an average of six people per household, means touching the lives of 18,000 people.

The Rural Self-Help Development Association (RSDA) is another local NGO that focuses on eradicating extreme hunger and improving the lives of rural Basotho by supporting sustainable agriculture, facilitating self-help, and enabling rural communities to become self-sustaining. The institution was established in 1991. Presently, the organization works with over 50 small-scale farming groups: schools, orphans and vulnerable children, and people living with HIV/AIDS support groups. The RSDA provides technical support to these communities through its experienced rural-based project staff. Notably, the RSDA in partnership with another NGO, the Denmark Lesotho Network (DLN), supports 40 farmers' groups in Mafeteng and Mohale's Hoek. They build the capacity of groups and individuals by offering savings- and loan strategies. Suharko (2007) highlighted a similar approach in Indonesia, where the unemployed put together their savings to offer each other loans to kick-start their income-generating projects to fight poverty. The RSDA also engages in activities that seek to build people's capacity in terms of advocacy and lobbying to hold government and corporates to account. It is worth noting that, of all respondent NGOs, the RSDA is the only one that reported engagement in advocacy and lobbying activities. The researchers are not entirely surprised because advocacy and lobbying by NGOs is minimal or barely noticeable in Lesotho, especially when compared to other regional countries. The apparent negligence of the NGOs in this regard is rather disconcerting.

Just like the government ministries, all NGOs cited a lack of adequate resources, especially funding, as the key challenge to the implementation of their programs. Some also cited a lack of cooperation and interference by political and community leadership as another impediment. There is also a lack of enthusiasm from target groups, especially when programs are designed to promote skills that would help individuals or groups to fend for themselves. This suggests that poor people are more motivated by programs that hand out consumable materials and much less so with skill-building programs. This was a point also echoed by government officials who vehemently argued that there were numerous government programs that targeted poor people, but whose 
potential beneficiaries did not take advantage of them unless they involved the direct handouts of goods, a behavior which the officials attributed to laziness. This contrasts with the Indian situation, where Suharko (2007) reported that the poor were very proactive in terms of seeking out solutions.

However, it is the researchers' view that there may be multifaceted reasons for the cited resistance, including paltry returns, mistrust, and dependence. Naturally, if individuals view what they will get as too little compared to the time and other resources they need to commit, they will surely resist engaging. Previous experiences with promised benefits that have failed to materialize breeds mistrust of any new initiatives. On the other hand, politicians cultivate dependence through their habit of dishing out goodies to poor people during election campaigns and making promises concerning the continuation of such handouts if they are elected. Most likely, a combination of these factors and many others are simultaneously influencing the reported behaviour. Surely, such lethargic attitudes towards government and NGO initiatives have more underlying causes than mere laziness. Such causes need to be unpacked and addressed accordingly if such programs are to achieve the desired results.

\section{Government-NGO coordination and the impact of the programs}

Apart from its regulatory role, the government does not seem to play any significant role in how NGOs go about assisting the poor in the country, apart from its provision of grants to those NGOs that look after orphans and elderly people. Both government and NGO officials admitted to a general lack of coordination between government and NGOs with regard to the planning and implementation of poverty reduction programs. As such, the duplication of efforts in some parts of the country is not uncommon, while other parts of the country that are in dire need are left unattended. Furthermore, a lack of coordination was also acknowledged among government departments which deal with poverty reduction issues as well as among the NGOs themselves. Clearly, this was a matter of concern to researchers, who believe a more coordinated approach by the government and NGOs would have a synergic effect and a greater impact on poverty reduction across the country.

Notably, there exists an umbrella organization for NGOs, the Lesotho Council of Non-Governmental Organizations (LCN), of which all respondent NGOs are registered members. The LCN was established in May 1990 with the objective of providing supporting services to the NGO community through providing networking and leadership training and development, disseminating information, capacity building, coordination, advocacy and representation when 
dealing with the government and the international community. The researchers observed that any coordination roles by LCN did not affect the operational level at which they could have maximized synergy.

Again, both the government and NGOs have not carried out any systematic assessment of the impact of their programs, although they generally believed that their efforts were indeed yielding desirable results as per their key objectives of poverty of reduction and economic development in general. Responding to the researchers' concerns regarding the lack of impact assessment of all those programs, the general position was that, although such assessments were noble, resource constraints always forced the institutions to choose between investing in those assessments and using scarce resources to assist more poor people.

\section{CONCLUSION}

There are many economic empowerment programs in operation across the country. According to official narratives, both the government and NGOs are apparently doing commendable work regarding economically empowering the poor, especially in terms of imparting technical and other life-skills such as entrepreneurial skills which enable recipients to become self-employed or enter formal employment. However, both the government and NGOs cited resource constraints as a major impediment to their efforts. Socio-political factors such as political interference by political leaders and a lack of enthusiasm about participating by target groups also render the benefactors' efforts less effective. It is the authors' view that further research that investigates the reasons behind the poor participation of target groups would be worthwhile.

\section{REFERENCES}

Abdullahi, Ibrahim - Sani Maiunguwa (2014), "Gender parity and poverty in rural households of Nigeria: Empowerment as a way forward. IOSR Journal of Humanities and Social Science”, Vol. 19, No 1, pp. 95-99.

Australian Government (2017), "Australia advancing women's economic empowerment through aid, trade and economic diplomacy", Barton, Department of Foreign Affairs and Trade

Babbie, Earl - Johann Mouton (2001), The practice of social research, Cape Town, Oxford University Press, Southern Africa 
Beierl, Stephan - Burchi, Francesco - Strupat, Christoph (2017), Economic Empowerment Pilot Project in Malawi. Bonn: German Development Institute. http://www.die-gdi.de

Clark David Alexander (2005), The Elgar Companion to Development Studies, Manchester, Global Poverty Group

Del Nnino, Carlo - Subbarao, Kalanidhi - Milazzo, Annamaria (2009), "How to make Public Works Work: A review of the Experiences", SP Discussion Paper No. 0905. Washington DC, World Bank

Diraditsile, Kabo (2017), "Challenges to Social Policies: A Critical Analysis of Youth Intervention Programmes in Botswana", Asian Journal of Social Science Studies, Vol. 2, No 1, pp. 74-82. http://dx.doi.org/10.20849/ajsss. v2i1.110

Dziobek, H. Claudia - Alberto F. Jiménez de Lucio - James Chan (2013), "Definitions of Government in IMF-Supported Programs", Retrieved from https://www.imf.org/external/pubs/ft/tnm/2013/tnm1301.pdf

Edwards, Michael (1999), "NGO Performance - What Breeds Success? New Evidence from South Asia", World Development, Vol. 28, No 2, pp. 361-374.

Hapazari Josphine (2016), The impact of Government and Non-Government Organisations' economic empowerment programmes with respect to poverty reduction and gender equality in Manonyane rural community between 2010 and 2015, Masters Thesis, University of KwaZulu Natal, South Africa, Faculty of Humanities

Hapazari Josphine (2017), "An assessment of the extent to which the Lesotho Government has economically empowered unemployed people", International Journal of politics and good governance, Vol. 8, No 1, pp. 1-22.

Handley, Geoff - Higgins, Kate - Bhavna, Sharma - Bird Kate - Diana Cammack (2009), Poverty and poverty reduction in Sub-Saharan Africa: An overview of key issues, London, Overseas, Development Institute.

Hulme, David (2001), "Reinventing the Third World State: service delivery and the civic realm," in: McCourt, W and Cheltenham, M. M.eds., The Internationalization of Public Management: Reinventing the Third World State, London, Edward Elgar Publishing Limited

International Fund for Agricultural Development (2010), Rural poverty report-2011, Rome, IFAD.

Kali, Moeketsi (2018), "Women Empowerment in Lesotho: Reality and/or myth?", International Journal of Scientific Research and Management Vol. 6, No 3, pp. 52-59. http://doi: 10.18535/ijsrm/v6i3.sh06

Keman, Hans (2017), Structure of Government, Amsterdam, Free University of Amsterdam. 
Kraal, Georg (2000), "Tracking trends in donor funding”, OD Debate Vol. 7, No 5, pp. 18-20.

Kumar, Neha - Nguyen, Phuong Hong - Harris, Jody - Harvey, Danny - Rawat, Rahul - Ruel, Marie T. (2018), "What it takes: evidence from a nutritionand gender-sensitive agriculture intervention in rural Zambia", Journal of Development Effectiveness Vol. 10, No 3, pp. 341-372. http://doi:10.1080/1943 9342.2018.1478874

Leakey, Roger R. B. - Atangana, Alain R. - Kengni, Edward - Waruhiu, Annabelle N. - Usoro, C. - Anegbeh, Paul O. - Tchoundjei, Zac (2002), (2002), "Domestication of Dacryodes edulis in West and Central Africa: Characterisation of genetic variation", Forests, Trees Livelihoods Vol. 12, pp. 57-72.

Lewis, David - Kanji, Nazneen (2009), Non-Governmental Organisations and development, New York, Routledge.

Lesotho Metrological Services (2013), Lesotho's Second National Communication under the United Nations Framework Convention on Climate Change. Lesotho Metrological Services, Lesotho. Accessed on 15 May 2016 http://unfccc.int/resource/docs/natc/lsonc2.pdf

Naher, Ainoon (2005), Gender, religion and development in rural Bangladesh. $\mathrm{PhD}$ Dissertation. Department of Ethnology, South Asia Institute, Heidelberg University.

Nthomang, Keitseope (2018), "Botswana's Ipelegeng Programme Design andImplementation: Reduction or Perpetuation/Entrenchment of Poverty?", Asian Journal of Social Science Studies Vol. 3, No 3, pp. 27-38.

OECD (2014), Enhancing Women's Economic Empowerment through Entrepreneurship and Business Leadership in OECD Countries

Polkinghorne, Donald. E (2005), "Language and meaning: Data collection in research", Journal of Counselling Psychology, Vol. 52, pp. 137-145.

Rantšo, A. Tšepiso (2015, November), "Youth unemployment and entrepreneurship in Lesotho". A seminar paper presented at the National University of Lesotho.

Suharko, Chen (2007, November), "The roles of NGOs in rural poverty reduction: The case of Indonesia and India". A working paper presented at the International Symposium Interdisciplinary Development Studies of Poverty Reduction Policies held by GSID-Nagoya University, Japan. Retrieved from http://personal.lse.ac.uk/lewisd/images/NonGovernmental\%20 Organisations $\% 20$ and $\% 20$ Development $\% 20$ vouchers.pdf

Taele, M. Benedict (2012). "Grid electrification challenges, photovoltaic electrification progress and energy sustainability in Lesotho", Renewable and Sustainable Energy Reviews, Vol. 16, No 1, pp. 973-998. 
Tesfay, Aregawi - Tadele, Haileslasie (2013), "The role of cooperatives in promoting socio-economic empowerment of women: Evidence from multipurpose cooperative societies in South-Eastern zone of Tigray, Ethiopia.", International journal of community development Vol. 1 No 1, pp. 1-11 DOI: $10.11634 / 233028791301325$

Twala, Chitja (2012), "The impact of rural development on poverty reduction in a post-apartheid South Africa: An ecological discourse", Journal of Human Ecology Vol. 40 No 3, pp. 213-221.

UNDP/Lesotho (2014), "Informative facts about Lesotho", Accessed 14 February 2017 http://www.ls.undp.org/content/lesotho/en/home/countryinfo. html

UN/DESA Population Division (2015), "World Population Prospects: The 2015 Revision. Key Findings and Advance Tables", ESA/P/PW Working Paper No.241. https://esa.un.org/unpd/wpp/Publications/Files/Key_Findings_ WPP_2015.pdf

World Bank (2012), World Bank Data, Washington DC, USA. 
